\title{
Dispositions: Ability and Assessment
}

\author{
Charles E. Notar (Corresponding Author) \\ Jacksonville State University \\ College of Education and Professional Studies \\ Department of Secondary Education \\ 700 Pelham Road North \\ Ramona Wood A3 \\ Jacksonville, Alabama 36265-1602, United States of America \\ Tel: 1-256-782-5832Ｅ-mail: cnotar@jsu.edu \\ Gena W. Riley, \\ Jacksonville State University, United States of America \\ College of Education and Professional Studies \\ Director of clinical experiences \\ E-mail: griley@jsu.edu \\ Dr. Phyllis W. Taylor \\ Jacksonville State University, United States of America \\ College of Education and Professional Studies \\ Department of Curriculum and Instruction \\ E-mail: ptaylor@jsu.edu
}


Roland A. Thornburg

Jacksonville State University, United States of America

College of Education and Professional Studies

Department of Health, Physical Education and Recreation

E-mail: rthornbur@jsu.edu

\author{
Raynard L. Cargill \\ Jacksonville State University, United States of America \\ College of Education and Professional Studies \\ Department of Secondary Education \\ Graduate Assistant \\ E-mail: jsu4084j@jsu.edu
}

\begin{abstract}
The article is a review of literature on dispositions and how the College of Education and Professional Studies, Jacksonville State University has implemented a program to help students identify and strengthen professional education dispositions and assess and assist students who do not display these appropriate professional educational dispositions.
\end{abstract}

Key Words: Dispositions, Internship, National Council for the Accreditation of Teacher Education, Professional Development 


\section{Introduction}

It is a fact today that the goal of teacher education programs is to train future educators in such a way as to produce highly qualified individuals who possess the knowledge, skills and dispositions they need to become effective teachers. Two key aspects of developing dispositions are definitional and philosophical (Dottin, 2009). There is a movement beyond the preservice teaching knowing and doing to being where the affective aspect of being a teacher must be assessed (Phelps, 2006). Education faculty not only are responsible for pre-service students mastery of knowledge and skills" but also are the pre-service students the "right sort" of person to be a teacher. These dispositions are called "virtue ethic" (McKnight, 2004). McKnight's belief that a code of ethics is the key to dispositions is support by Burant, Chubbuck and Whipp (2007).

Teacher education has moved from knowledge, skills, and attitudes to knowledge, skills, and dispositions (Villegas, 2007). Besides having academic qualifications a professional teacher must act in an ethical manner based on an explicit or implicit code of conduct through the development of characteristics of a professional and model professionalism every day (Kramer, 2003).

Knowledge, skills and dispositions are imbedded within the standards of the National Board for Professional Teaching Standards (NBPTS), the National Council for the Accreditation of Teacher Education (NCATE), the Interstate New Teacher Assessment and Support Consortium (INTASC), as well as other content area organizations (Thornton, 2006; Da Ros-Voseles and Moss, 2007). A strong correlation has been drawn between the dispositions of teachers and the quality of student learning. Some colleges of education are currently beginning to define dispositions while others are refining dispositional requirements in their programs as they begin to address the assessment process. In fact, institutions across the nation since NCATE 2000 Standards are attempting to more explicit the role of teacher dispositions in the preparation of future educators (Callahan, Wasicsko, \& Wirtz, 2004). In order to effectively produce strong teacher candidates, most colleges of education embrace the commonly held belief they must develop or find appropriate measurement tools such as rubrics, rating scales, self-reflection evaluations, and checklists and begin objectively assessing the dispositions of pre-service teachers, both in their internship as well as practicum classes and coursework.

\section{Definition}

Dispositions have been defined by NCATE (2002) as the values, commitments, and professional ethics that influence behaviors toward students, families, colleagues, and communities and affect student learning, motivation, and development as well as the educator's own professional growth. NCATE further defines effective teachers as those who possess content knowledge in their subject area, pedagogical skills, and positive dispositions. Dispositions are at the are the being of a person, and teacher educators are there to strengthen certain dispositions (Freeman, 2004). There are five dispositions of effective teachers: 
empathy, positive view of others, positive view of self, authenticity, and meaningful purpose and vision (Combs, 1999; Usher, 2002).

Disposition can be defined as a tendency to exhibit frequently, consciously, and voluntarily a pattern of behavior that is directed to a broad goal (Da Ros-Voseles and Moss, 2007). Another definition of dispositions sees them as behaviors based on a meaning-making system that results in attitudes, values and beliefs (Eberly, Rand, and O’Connor, 2007). An opposing view is that weak dispositions should be seen as conceptualize problems rather than one of "beliefs" (Raths, 2001).

A starting point on defining dispositions would be NCATE (2006) definition of dispositions as values, commitments, and professional ethics that influence a teacher's behavior toward his/her students, families, colleagues, and communities. The dispositions affect student learning, student motivation, and student development. They also impact an educator's own professional growth. Dispositions are guided beliefs and attitudes related to values such as caring, fairness, honesty, responsibility and social justice (Singh and Stoloff, 2007).

\section{How Dispositions Are Assessed}

Since there seems to be a direct correlation between effective teaching and the dispositions of the teacher, colleges of education must find ways to nurture them, contribute to their growth and find a valid and reliable way to assess dispositions. Because there is a renewed interest in this not-so-new concept, many institutions are spending vast amounts of time, energy and money taking a close look at their own dispositional assessment techniques for teacher candidates as well as participating in ongoing research to determine the most effective way to prepare their future teachers in the area of dispositions. Key faculty members in the College of Education are investing their time in reviewing literature, attending conferences and becoming champions in their respective colleges to undertake this arduous task.

There are several ways to look at dispositions: "entity" v "incremental" "separate” v. "holistic" "screening individuals" v. "building a professional community". Once you have determined which way you want to look at dispositions you must determine how you will assess dispositions (Diez, 2007).

Dispositions are environmentally sensitive, meaning they are acquired, supported, or weakened by interactive experiences in an environment with significant adults and peers Thus, it is important for teacher educators to provide classroom experiences that support positive dispositions. Further, we can differentiate dispositions either desirable or undesirable (Bertram and Pascal, 2002).

Researchers are now turning their attention to tracking the development of children's learning dispositions (Carr \& Claxton 2002). A focus on dispositions sends the message to future teachers that it is no longer adequate to plan only for children's knowledge and skill learning according to Wheatley (2002).

The first to focus on reflection in teaching as a method of thinking that results from direct experience leading to inquiry and the resolution of practice-based problems was John Dewey. 
Reflection and inquiry are the best way to develop appropriate dispositions (Titone, Sherman, and Palmer, 1998). While there is a concentrated effort on dispositions today critical reflection based on real school observations in addition to coursework/readings is a crucial factor in encouraging preservice teachers to develop a set of beliefs coinciding more readily with the philosophy of their teacher education program (Yost, 1997). Lamson, Aldrich, and Thomas (2003) concur with Yost stating that social inquiry is useful in developing appropriate teacher dispositions. A key to the strategy working is self-reflection.

Teachers must know themselves, what they believe, their values, and how those intangibles will guide them in their classroom. Portfolio development provides the vehicle for per-service teachers to reflect on their beliefs about teaching and learning. Developing a portfolio provides students the opportunity to self-reflect, explore and discover the dispositions they hold as future teachers.

Learning climates and expectations must be created where self-reflection and critical cultural consciousness are part of the routine, normative demands of teacher education if systemic change is to occur. Change can only occur in the quality of teachers that affect student learning when dispositional and instructional changes accompany a reframing of the curriculum (Talbert-Johnson, 2006).

One process to help teacher educators in screening for candidates' inappropriate dispositions and behaviors is based on a documented record of attempted interventions and the success or failure of those interventions. This documentation can provide faculty in directing candidates to pursue other careers or dismiss them from the program prior to student teaching (Burke, 2002).

Colleges that establish dispositions committees to broadly assess individual pre-service teacher's dispositions. Should understand dispositions are complex and fraught with pitfalls and any proposal should define disposition, which should be addressed and level of dispositional tolerance (Nelson, 2002).

Henderson State University assess dispositions with a entry and exit interview from teacher education program, performances during internship and self-assessments (Harrison, McAffee, Smithey, and Weiner, 2006). Another step that can be added to improve dispositions in field experiences is to establish "cohort collaboration", mentors, and produce teacher work samples (Branyon, 2008).

Adding strategies that teacher educators can use to nurture dispositions such as creating a safe learning environment, encouraging risk taking, modeling desired practices, providing opportunities to plan, act, and reflect on dispositions in classroom activities and assignments could be a means of providing Branyon teacher work samples (Quiping, et. al., 2005).

Regardless of what is being done assessing dispositions remains a challenge that needs to be addressed. One way is through informal means. The best true measure of appropriate dispositions derives from observing classroom practice (Phelps, 2006). We need to give more focused attention to issues of validity and reliability in assessment of teacher candidates' disposition (Villegas, (2007). 


\section{What is the Right Track to Promote Dispositions}

The role of the teacher education program is to mold the teacher candidate through a developmental process into an effective teacher through the program's conceptual framework. Teacher educators should first assist candidates in becoming conscious of their dispositions, find out if they want to change, and then create circumstances in which they can begin this developmental transformation. It is a holistic development of the candidate through a variety of experiences in their teacher education program. In some teacher education programs, there are candidates who may possess the knowledge and skills required of an effective teacher yet lack the positive dispositions necessary to complete the holistic development of that ideal effective teacher. NCATE has given the charge to assess dispositions in teacher education

As teacher educators, we must discover which teacher behaviors promote desirable student performance. In 2003 a list of competencies a beginning teacher should have (NCATE, 2003. This is the model most teacher education programs have followed. Is this the disposition checklist that should be used or is it much more than a checklist (Wilson, Thornburg \& Riley, 2005)? How do colleges and universities look at the problem of teacher candidates who should not become teachers is very important. Advocates on solving this problem say the use of rubrics to assess dispositions is important tool. When using a rubric there is a need for an N/A so that a rubric can be used in any situation (Wayda and Lund, 2005).

Defining and assessing dispositions creates a challenge for teacher education institutions. There is no universal list of teacher dispositions for educational programs to follow. There has been an immense amount of research that has produced an array of possible characteristics that directly correlate to teacher effectiveness. Although the terminology differs from one teacher education program to another, common characteristics include but are not limited to such things as enthusiasm, sensitivity, responsibility, commitment, professionalism, skillful preparation, a sense of respect for others, communication, and appropriate dress, deportment and demeanor. In defining dispositions one school of thought focus on teacher behaviors, teacher characteristics, and teacher perceptions (Callahan, Wasicskil, and Wirtz, 2004).

Our responsibility to the teacher education candidate becomes a discourse on what positive dispositions are and how to recognize them. It is our job to help the candidate understand the connection between these dispositions and student achievement. Candidates should be placed in situations to observe and work with model teachers who exhibit positive dispositions as much as possible during their time in the teacher education program.

Literature from both the academic and professional fields focused attention on the moral dimensions of teaching and the ethical demands they place on the daily practice of teachers. In teaching, core principles relating to virtues such as honesty, justice, fairness, care, empathy, integrity, courage, respect, and responsibility should guide conduct and interpersonal relations (Campbell, 2006). Others see dispositions as divided into beliefs and attitudes and personality traits (Burant, Chubbuck and Whipp, 2007) and still others identified attitude and behavior as major components (Tichenor and Tichenor, 2004). Researchers identified five areas of professionalism: character, commitment to change and professional growth, content 
knowledge, pedagogical knowledge, and obligations and working relationships beyond the classroom. Teachers need to possess the characteristics of patience, determination, courage, and respect for students. This category also entails being confident, organized, flexible, calm and resilient in all circumstances. However, teacher professionalism is not confined to the classroom but extends outside the classroom in the areas of service and community. Teachers must model ethical behavior and exhibit integrity. Modeling this behavior is one of the most significant ways to motivate students.

\section{Our Approach}

The first step in establishing a process for assessing candidate's dispositions is to define the term and the criteria by which a candidate's disposition is evaluated. Implementing the definition used by NCATE (2002), dispositions are guided by beliefs and attitudes related to values such as caring, fairness, honesty, responsibility, and social justice. As teacher educators, our commitment is to the development and growth of our teacher candidates not only with respect to content and pedagogical knowledge and use but also in the areas of personal development and professionalism. However, the assessment of these dispositions is subjective and abstract at best due to their uniqueness. Are they directly observable? Are they directly linked to certain behaviors or patterns of behavior in a one-to-one fashion? Can they be readily assessable using the instruments of measurement that have become rather standard in the social sciences - checklists, inventories, and self report? (Usher, Usher, \& Usher, 2003). The answer to these questions is critical to the assessment of dispositions. Even well informed teacher education faculty members who are highly trained in recognizing appropriate dispositions have great difficulty in their assessment. The challenge exists in measuring something that is sometimes immeasurable. Can a rubric, a checklist, or other feedback instrument that measures something as subjective as a disposition be effective enough to evaluate or challenge a person's ability to teach in a classroom? Is there a system to evaluate dispositions that is clear, fair, and appropriate for all students in education programs? It is critical that candidates come to know, understand, and demonstrate professional dispositions and interactions once they enter the teacher education program.

In accordance with the charge for assessing the dispositions of teacher education candidates, coupled with faculty's beliefs that some candidates may not always exhibit dispositions deemed appropriate to professional education, efforts should be taken to institute a system for assessing and monitoring the dispositions of teacher candidates. Through the involvement of faculty and school professionals it is clear that efforts aimed at implementing this system need to be directed in two areas: 1. creating a feedback instrument that addresses the major criteria of appropriate dispositions, while also providing opportunities for remediation. 2 . Creating a clear, defensible and fair protocol for handling assessment feedback received on candidates. Schools of education ought to be able to show how they are preparing students to develop particular abilities in a way that is credible and defensible (Whaley, 1999).

Efforts should be made to create an appropriate strategy for handling feedback. The teacher education program should be committed to the development of competent new teachers and thus have a program fully engaged with the standards and with performance assessments. In 
recognizing the importance of assessing and ensuring the appropriate professional disposition of candidates, the teacher education program should develop a process by which these characteristics can be examined and ensured. Although this process appears simple, the examination of character is not. A candidate's disposition has not in the past been formally scrutinized as part of his or her preparation for teaching. The high level of subjectivity of such assessment is filled with risks. Yet as standards are raised, dispositions are indeed one area that must be examined.

\section{The Process}

Why is it impossible to standardize the assessment of pre-service teacher dispositions? Dispositions are not necessarily attached to skill and content knowledge and are not easily detectable. In fact, one might expect to see such qualities as kindness, honesty, patience, and fairness in a prospective teacher. However, assessing the qualities of kindness, honesty, patience, and fairness in current teacher assessment models is virtually impossible because of their non-technical attributes. Also there is a challenge when addressing human behavior, reaching consensus and mutual agreement regarding the teaching and assessment of candidate dispositions (Danielson, Edick \& Edwards, 2007). Perhaps the actual language of dispositional assessments is confusing and difficult to articulate. Another underlying reason for the discrepancy perhaps is that the expectations of teacher candidates by the faculty and the actual dispositions exhibited by the students are incongruent. The relational aspects of teaching are sometimes hard to detect.

As the charge is given, the teacher education program should first reflect upon its own understanding and definition of dispositions it deems vital to becoming an effective teacher. It should examine how dispositions should be instilled and assessed within the educational program. The process should be documented through ongoing data collection and analysis of this process. Secondly, the formation of a committee of the major stakeholders should determine (1) how they define dispositions and (2) how they are implementing teacher dispositions into the courses they are teaching, the dispositions they look for when evaluating student teachers, and the dispositions they look for in potential employees.

Although the integration of dispositions within coursework is not necessarily a common practice among educational faculty, it definitely would prove to be beneficial. Teacher candidates who are exposed to dispositional expectations early and who have a clear understanding of the exact definitions of teacher dispositions most likely will benefit in their college classrooms, their practicum experiences and their internships. Possibilities for the integration of dispositions into coursework include such things as portfolios, discussions, case studies, field experience evaluation and standards (Danielson, Edick, \& Edwards, 2007). Another important issue is paramount in the understanding of educator dispositions and their integration within candidates' coursework. Teacher candidates can benefit greatly from modeling desirable dispositions by their education professors, who should be very conscious of this responsibility and demonstrate appropriate behaviors to the pre-service teachers through classroom interaction and advising (Davis \& Stewart, 2005). Additionally, educational faculty should know and understand the dispositions of effective teachers, so as 
to design experiences that will help to develop theses characteristics in students and help students determine their dispositional strengths and weaknesses (Taylor \& Wasicsko, 2000).

One way to define dispositions of a program is to conduct a survey of the stakeholders, such as faculty, cooperating teachers, and local school administrators. Those dispositions are then selected and matched with a justification relative to the teacher education program's conceptual framework. Once dispositions become aligned with professional literature and the program's conceptual framework, the implementation process can begin. After the formulation of a Dispositions Form, it can be incorporated and used as soon as the student is admitted to the teacher education program. What the teacher education program will discover is its own faculty will begin to look closer at education candidates' dispositions in methods classes, practicum, and ultimately, the internship. The importance of identifying those dispositions early in a candidates' program of study is soon realized. This should reduce the number of concerns later when it seems too late to remove pre-service teachers with poor dispositions from the classroom during their internship.

What is the proper protocol for handling of candidates with poor dispositions? When a faculty member believes a candidate has displayed poor dispositions in the classroom, should they be dismissed, remediated, or simply ignored with hope for improvement? It is the responsibility of the education faculty to assist in the development of these positive dispositions; therefore it is imperative dialogue takes place concerning dispositions and a remediation process begin. When negative dispositions are discovered, this information should be housed in a central location of the teacher education program for future reference. If similar dispositional problems arise in the future, further action may need to be taken. The teacher education program will find faculty will be more apt to expose these negative dispositions of education candidates if they know action is going to take place. If certain dispositions of candidates persist, the teacher education program may have no other recourse than to dismiss the candidate from the program. It is the hope of the teacher education program that positive teacher dispositions can be instilled in initial teacher candidates throughout their various levels of instruction and ultimately in the internship and revealed in their first teaching job as a teaching professional.

Even though disposition assessments vary from college to college, hopefully, the goal of educational institutions is to use these assessments to promote the awareness of dispositions desirable in teachers, as well as nurture and mentor pre-service teachers in the development of dispositions (Braun, Dukes, Koorland \& Stoddard, 2007). Future educators should be informed early in their programs of expected dispositions and encouraged to become aware of appropriate behaviors synonymous with the teaching profession.

\section{Dispositions}

Dispositions are aspects of one’s nature that include temperament, character, and personality.

$>\quad$ Pedagogical Dispositions are "The values, $\underline{\text { commitments, }}$ and professional ethics that influence behaviors toward students, families, colleagues, and communities and affect student learning, motivation, and development as well as the educator's own professional growth. 
These dispositions are guided by beliefs and attitudes related to values such as caring, fairness, honesty, responsibility, and social justice. For example, they might include a belief that all students can learn, a vision of high and challenging standards, or a commitment to safe and supportive learning environment.”

Professional Dispositions at JSU

1. Attendance/Punctuality - Candidate follows required course attendance policy; arrives early and never leaves class.

2. $\quad$ Timeliness w/ Assignment - Assignments are turned in on time.

3. $\quad$ Appearance - Candidate dresses in an appropriate manner; is well-groomed.

4. $\quad$ Poise - Appears to be confident and consistently composed.

5. $\quad$ Attitude - Displays appropriate professional behavior and a positive attitude; acts in a mature manner; accepts constructive criticism.

6. $\quad$ Initiative - Participates; is inquisitive; will assume added responsibilities.

7. $\quad$ Responsiveness to Feedback - Accepts feedback about performance and will refine practice.

8. $\quad$ Rapport - Effective in establishing a rapport with others; exhibits an appropriate level of caring and respect.

$\checkmark \quad$ Evaluating Candidate Dispositions

$\checkmark \quad$ Professional dispositions will be evaluated throughout the candidate's program.

$\checkmark \quad$ If the candidate fails to consistently display appropriate professional dispositions, he or she will be required to successfully complete the PRIME Candidate Program.

$\checkmark \quad$ The purpose of the PRIME (Process for Remediating Identified Marginal Education) Candidate Program is to identify, remediate, and counsel those individuals who exhibit characteristics associated with failure in their teacher education program as early as possible...

The College of Education and Professional studies "Evaluating Candidate Dispositions: JSU CEPS Professional Dispositions Form.doc" can be found at the following url: https://c1.livetext.com/misk5/formz/public/25868/73QSf32TPg

\section{Conclusion}

The quality of the education our children receive depends directly upon the quality of the teachers in our schools. Effective teaching happens when teachers know their subjects, have significant skills, and possess dispositions that foster growth and learning in students (Wasicsko, 2002). Although we have been mindful to disseminate pre-service teachers with the dispositions expected of teaching professionals, there has been little research in the area of methods or techniques used to monitor and assess the disposition and professional 
behavior. While teacher candidate dispositions are thought to play an important role in teaching, more attention needs to be given to this domain (Bouley-Picard, 2005). At the University of Memphis the assessing of dispositions is worth the effort involved and is a critical dimension of professional development (Rike and Sharp, 2008).

It is important to have clear statements of professional expectations that can be used as criteria in making judgments about dismissing candidates whose behavior is harmful to others or inappropriate for professional practice (Diez, 2007). Dispositions build a teacher's ability to work as part of a professional community to support learning for all students reducing the achievement gap thus addressing the key issue facing $21^{\text {st }}$ century educators. It is no longer acceptable for teacher candidates to possess only skills and knowledge necessary to teach children. Now, future teachers must understand their pivotal role (Da Ros-Voseles and Moss, 2007). Teacher educators must be more effective in producing educators who have the disposition necessary to positively impact children during their teaching career. If they are not effective, then changes must be made in the preparation of teachers (Wasiesko, 2002).

\section{References}

Bertram, T., \& Pascal, C. (2002). What counts in early learning. In Contemporary Perspectives in Early Childhood Curriculum, eds. O. N. Saracho, \& B. Spodek, 241-56. Greenwich, CT: Information Age.

Burke, P. Y. (2002). A mechanism for monitoring dispositions in preservice teachers. Childhood Education, 78(4), 224-K.

Bouley-Picard, T. M. (2005, November). The development of an assessment of teacher candidates' professional dispositions in classroom interactions. Paper presented at the Fourth Annual Symposium on Educator Dispositions, Northern Kentucky University, Highland Heights, KY.

Branyon, J. (2008). Using mentoring and cohort collaboration: Enhancing teacher quality in pre-service teachers. Delta Kappa Gamma Bulletin, 74(3), 35-38.

Braun, B., Dukes, L., Koorland, M., \& Stoddard, K. (2007). Building professional dispositions in preservice special educators: Assessment and instructional tactics. Journal of University Teaching and Learning Practice. 411, 28-39.

Burant, T. J., Chubbuck, S. M., \& Whipp, J. L. (2007). Reclaiming the moral in the dispositions debate. Journal of Teacher Education, 58(5), 397-411.

Callahan, C. J., Wasicsko, M. M., \& Wirtz, P. (2004). Integrating dispositions into the conceptual framework: Four a priori questions. Retrieved June 17, 2007. [Online] Available:

http://www.educatordispositions.org/dispositions/four\%20a\%20priori\%20questions.pdf

Campbell, E. (2006). Ethical knowledge in teaching: A moral imperative of professionalism. Education Canada, 46(4), 32-35. 


\section{Macrothink

Carr, M.; \& Claxton, G. (2002). Tracking the development of learning dispositions. Assessment in Education: Principles, Policy \& Practice, 9(1), 9-37.

Combs, A. W. (1999). Being and Becoming: A Field Approach to Psychology. New York, Springer.

Danielson, L., Edick, N., \& Edwards, S. (2007). Dispositions: Defining, aligning and assessing. Academic Leadership Retrieved June 25, 2007. [Online] Available:

http://www.academicleadership.org/emprical_research/Dispositions_D.

Da Ros-Voseles, D., \& Moss, L. (2007). The role of dispositions in the education of future teachers. Young Children, 62(5), 90-96.

Davis, S., \& Stewart, P. (2005). Developing dispositions of pre-service teachers through membership in professional organizations. Journal of Authentic Learning, 2, 37-46.

Diez, M. E. (2007). Looking back and moving forward: Three tensions in the teacher dispositions discourse. Journal of Teacher Education . 58(5), 388-396.

Dottin, E. S. (2009). Professional judgment and dispositions in teacher education. Teaching \& Teacher Education, 25(1), 83-88.

Eberly, J. L., Rand, M. K., \& O'Connor, T. (2007). Analyzing teachers' dispositions towards diversity: Using adult development theory. Multicultural Education, 14(4), 31-36.

Freeman, L. (2004). Dispositions in teacher education. Retrieved October 22, 2005. [Online] Available: http://larryfreeman.net/aactedisp0207.pdf.

Harrison, J., Smithey, G., McAffee, H.,\& Weiner, C. (2006). Assessing Candidate Disposition for Admission into Teacher Education: Can Just Anyone Teach? Action in Teacher Education, 27(4), 72-80.

Kidd, J. K., Sánchez, S. Y., \& Thorp, E. K. (2008). Defining moments: Developing culturally responsive dispositions and teaching practices in early childhood preservice teachers. Teaching \& Teacher Education, 24(2), 316-329.

Kramer, P. A. (2003). The ABC's of Professionalism. Kappa Delta Pi Record, 40(1), 22-25.

Lamson, S. L., Aldrich, J. E., \& Thomas, K. R. (2003, February). Using Social Inquiry Strategies To Enhance Teacher Candidate Dispositions. Paper presented at the Annual Meeting of the Association for Teacher Educators, Jacksonville, FL.

McKnight, D. (2004). An inquiry of NCATE's move into virtue ethics by way of dispositions (Is This What Aristotle Meant?). Educational Studies, 35(3), 212-230.

National Council for the Accreditation of Teacher Education. (2006). Professional Standards for the Accreditation of Schools, Colleges, and Departments of Education. Washington, D.C.

National Council for the Accreditation of Teacher Education. (2003). Professional Standards for the Accreditation of Schools, Colleges, and Departments of Education. Washington, D.C. 
National Council for the Accreditation of Teacher Education. (2002). Professional Standards for the Accreditation of Schools, Colleges, and Departments of Education. Washington, D.C.

Nelson, M. (2002, February). Identifying desirable pre-service teacher dispositions: An intractable problem? Paper presented at the $54^{\text {th }}$ annual meeting of the American association of Colleges for Teacher Education, New York, NY. (ED463258)

Phelps, P. H. (2006). The dilemma of dispositions. Clearing House: a Journal of Educational Strategies, Issues and Ideas, 79(4), 174-178.

Quiping, C., Nissen, H., McMurray-Schwarz, P., \& Baum, A. (2005). Identifying and nurturing dispositions: A summary and Rejections. Pre-conference poster session presented at the annual conference of the National Association of Early Childhood Teacher Educators, December, Washington, D.C.

Raths, J. (2000, November). Teachers' Beliefs and Teaching Beliefs. In: Early Childhood Research \& Practice: An Internet Journal on the Development, Care, and Education of Young Children, 2001; see PS 029 507. Published biannually. Paper presented at a symposium honoring ECRP editor Lilian G. Katz (Champaign, IL.)

Rike, C., \& Sharp, L. K. (2008). Assessing Preservice Teachers' Dispositions: A Critical Dimension of Professional Preparation. Childhood Education, 84(3), 150-153.

Singh, D. K.; \& Stoloff, D. L. (2007, November). Measuring Teacher Dispositions. Paper presented at the National Fifth Annual Symposium on Educator Dispositions, Erlanger, KY.

Talbert-Johnson, C. (2006). Preparing highly qualified teacher candidates for urban schools: The importance of dispositions. Education \& Urban Society, 39(1), 147-160.

Taylor, R. L., \& Wasicsko, M. M. (2000). The Dispositions to Teach. A paper presented at the annual meeting of the Southern Region Association of Teacher Educators (SRATE) Conference, Lexington, KY. Retrieved June 18, 2007. [Online] Available: http://www.educatordispositions.org/dispositions/The\%20Dispositons\%20to\%20Teach.pdf

Thornton, H. (2006). Dispositions in action: Do dispositions make a difference in practice? Teacher Education Quarterly. Retrieved June 19, 2007. [Online] Available: http://findarticles.com/p/articles/mi

Tichenor, M S., \& Tichenor, J. M. (2004). Understanding teachers' perspectives on professionalism. The Professional Educator, 27(1 \& 2), 89-95.

Titone, C., Sherman, S., \& Palmer, R. (1998). Cultivating student teachers' disposition and ability to construct knowledge. Action in Teacher Education, 19(4), 76-87.

Usher, D. (2002). Arthur Combs' five dimensions of helper belief reformulated as five dispositions of teacher effectiveness. Paper presented at the First Annual Symposium on Educator Dispositions: Effective Teacher - Effective Person, Richmond, KY. 


\section{Macrothink}

International Journal of Education

ISSN 1948-5476

2009, Vol. 1, No. 1: E4

Usher, D., Usher, L,. \& Usher, M. (2003). Nurturing five dispositions of effective teachers. Paper presented at the $2^{\text {nd }}$ National Symposium on Educator Dispositions, Eastern Kentucky University, Lexington, KY.

Villegas, A. M. (2007). Dispositions in teacher education. Journal of Teacher Education, 58(5), 370-380.

Wasicsko, M. (2002). Assessing educator dispositions: A perceptual psychological approach.

[Online] Available:

www.educatordispositions.org/dispositions/Training\%20Materials/Manual103.pdf.

Wayda, V., \& Lund, J. (2005). Assessing Dispositions: An Unresolved Challenge in Teacher

Education. Journal of Physical Education Recreation and Dance JOPERD, 76(1), 34-41.

Whaley, D. C. (1999). Assessing the disposition of teacher education candidates. Retreived April 2009, [Online] Available:

www.pearsonschool.com/live/assets/200727/1999_11Whaley_414_1.pdf

Wheatley, K (2002). Teacher persistence: A crucial disposition, with implications for teacher education. Essays in Education 3 (Fall). [Online] Available:

wwwusca.edu/essays/ vol32002/wheatley.pdf.

Wilson, J., Thornburg, R., \& Riley, G. (2005, November 17 - 18). Tracking the dispositions of in-service teachers: What we are learning. Paper presented at the Fourth Annual Symposium on Educator Dispositions, Northern Kentucky University, Highland Heights, $\mathrm{KY}$.

Yost, D. S. (1997). The moral dimensions of teaching and preservice teachers: Can moral dispositions be influenced? Journal of Teacher Education, 48(4), 281-92. 